\title{
Concerned scientists, pragmatic politics and Australia's green drought
}

\section{Paper submitted to Science and Public Policy}

\begin{abstract}
The Wentworth Group of Concerned Scientists formed in Australia in 2002 in response to calls to 'drought-proof' the continent. Their model of engagement between science and public policy involves: clear simple science communication which keeps scientific uncertainty and debate out of public view; pragmatic politics which works within rather than challenges the dominant political agenda; and a focus on providing solutions rather than describing problems. This model has been successful in achieving level policy reform at the expense of more participatory and critical approaches to ecological science and politics.
\end{abstract}

\section{Introduction}

The Wentworth Group of Concerned Scientists formed in Australia in late 2002 as an expert voice of reason in an increasingly irrational public debate about droughtproofing the continent. During August and September it had become apparent that most of Australia was in drought and that agricultural production was likely to be severely reduced. The drought and its impacts on farmers, farm families, farm contractors and workers, rural towns and businesses, and the economy received increasing attention in the media (Bell and Moller, 2006). In response to increasingly desperate reports of the impacts of drought on rural communities, the Farmhand Appeal was formed by prominent businessmen and media personalities in early October to raise funds to provide charity relief to farmers and others affected by drought, and to investigate options for future drought-proofing Australia. Talk-back radio presenter and Farmhand spokesman Alan Jones revived old, ecologically contentious ideas for 'turning the rivers inland' to provide consistent water resources for agriculture and rural communities. In turn, this prompted the formation of the Wentworth Group of Concerned Scientists a few weeks later, with their catch-cry 'you can't drought-proof Australia' and a five point plan for reform of Australian land and water policy. 
The formation of the Wentworth Group came to represent a clear model for how science can engage with the public in Australia, as well as gathering together prominent scientists into a coherent force in natural resource policy and debate. As leading scientists in a small national community, they constituted a particular mode of relationships between science, the public and politics, providing an instructive case study of the shifting nature of these relationships in liberal democratic societies.

The 'Wentworth Model' of the engagement between science, the public and politics is fundamentally pragmatic. It aims to get scientific issues and environmental policy reform on the agenda in the way that they are most likely to be accepted. According to the Wentworth Model, scientific ideas are open to debate behind the closed doors of research, but science must be presented to a sceptical and easily confused public as clear, unequivocal truths; science must present solutions, rather than pointing out problems; and science should be spoken in the language of power to work within rather than challenge the dominant political agenda.

This paper describes the rise of the Wentworth Group to a position of prominence as a coherent actor in natural resource policy in Australia and identifies a particular mode of engagement between science, the public and politics. It presents the results of an analysis of newspapers, magazines, radio and television transcripts reporting on the Wentworth Group, academic papers written in response to their first major report, and speeches by prominent members of the Group explaining their success. The public fate of the Future Dilemmas report on population and resource scenarios in Australia, presented by a second group of scientists in November 2002, is compared with the Wentworth Group's reception to highlight some of the implications that the Wentworth Model of science and public engagement has for the definition of 'good science' and environmental discourse.

\section{Drought in 2002}

In the second half of 2002 most of Australia was in the grip of a serious and worsening drought. Droughts are not unusual in Australia but by September 2002 drought had become a major news story and was an issue of increasing public concern. In early October a group of media personalities and businessmen had lunch together to decide what should be done about drought in Australia. They were 
concerned with providing relief to those affected by the current drought and the need to develop longer term strategies for 'drought-proofing' Australia. The Farmhand Appeal was set up at the luncheon gathering as a charity to address these issues, with talk back radio host and former national rugby coach Alan Jones as its spokesman. Jones promoted the Appeal heavily on his daily radio program and steered the discussion of drought-proofing towards ideas about dam building, of turning rivers inland and stopping the 'wastage' of water flowing from the interior of Australia to the sea.

Australia has a highly variable climate. Drought is a regular climatic event. Drought features prominently in Australian history and culture, and how to respond to drought has been a political, ecological, economic and social dilemma since soon after European colonisation (Bonyhady, 2000; Botterill and Fisher, 2003). Drought has caused much despair and surviving drought is a prominent element in the colonial Australian culture of the stoic battler, surviving through hard work and persistence in a battle against the environment (Ward, 1966). The Farmhand Appeal and Alan Jones drew on these persistent myths of Australian culture in reviving historical, nation building proposals for engineering works to provide the water needed to relieve Australian agriculture from the tyranny of drought.

Unfortunately, along with the development of agriculture, the implementation of such engineering schemes in Australia's major river systems has resulted in severe ecological degradation (Walker, 1994; Ball et al., 2001). The re-emergence of calls for drought-proofing schemes prompted another group of prominent Australians to gather for a meal. With philanthropic funding from a little known millionaire, aged care businessman, Robert Purves, the World Wide Fund for Nature in Australia (WWF Australia) invited a group of leading environmental scientists and advisors to dinner. The purpose of the dinner meeting at Sydney's five star Wentworth Hotel was to discuss how best to respond to the Farmhand Appeal, Jones, and the ecologically dangerous ideas about drought-proofing that were getting so much media coverage. Taking their name from the hotel where they were dining, the Wentworth Group of Concerned Scientists emerged from that meeting to transform public discourse about drought, water and natural resource policy in Australia (Grimm, 2002). 


\section{The Wentworth Group}

The Wentworth Group of Concerned Scientists entered the debate about droughtproofing Australia with a five point plan that became the basis of their Blueprint for a Living Continent, which was released on 1 November (Wentworth Group, 2002). The Group consisted of eight senior environmental scientists, an economist, a farmer and an environmental policy specialist. The Wentworth Group of Concerned Scientists are: Leith Boully (farmer and rural community representative), Peter Cosier (policy advisor), Peter Cullen (ecologist), Tim Flannery (palaeontologist), Ronnie Harding (biologist), Steve Morton (ecologist), Hugh Possingham (mathematical ecologist), Denis Saunders (ecologist), Bruce Thom (geomorphologist), John Williams (hydrologist), and Mike Young (economist). Several of the group members, notably Peter Cullen, Tim Flannery and John Williams, had well established media profiles, a factor which assisted their swift rise to prominence.

In calling themselves 'concerned scientists', the Wentworth Group were drawing on an international tradition of scientists speaking out as the voice of reason in public debates about morally fraught, politically charged issues. The Union of Concerned Scientists, founded by faculty at Massachusetts Institute of Technology who were alarmed by the continued misuse of science and technology for military purposes, is perhaps the most famous exemplar of a proactive intervention by scientists in complex public debate (Downey, 1988). However, the Wentworth Group are significantly different to the Union. While the Union of Concerned Scientists deliberately formed in opposition to the governing ideology, the Wentworth Group strategically positioned themselves within the prevailing neo-liberal political agenda.

The key message from the Wentworth Group was that Australia can't be droughtproofed and that Australians need to learn to live with the landscape. Prior to its public release, the Blueprint was presented to the Prime Minister and State Premiers (Cullen 2004). The five main points in the Blueprint, which outlined how Australians should live in the landscape, were:

1. Clarify water property rights and the obligations associated with those rights to give farmers some certainty and to enable water to be recovered for the environment 
2. Restore environmental flows to stressed rivers, such as the Murray and its tributaries

3. Immediately end broadscale landclearing of remnant native vegetation and assist rural communities with adjustments. This provides fundamental benefits to water quality, prevention of salinity, prevention of soil loss and conservation of biodiversity

4. Pay farmers for environmental services (clean water, fresh air, healthy soils). Where we expect farmers to maintain land in a certain way that is above their duty of care, we should pay them to provide those services on behalf of the rest of Australia.

5. Incorporate into the cost of food, fibre and water the hidden subsidies currently borne by the environment, to assist farmers to farm sustainably and profitably in this country (Wentworth Group, 2002: 4).

With favourable media and government responses and with the former chair of the Prime Minister's Science, Engineering and Innovation Council (PMSEIC), Peter Cullen, as its spokesperson, the Wentworth Group began a swift rise to prominence as a united force in Australian natural resource policy. The Wentworth Group, and Cullen in particular, seemed to bring the environment to the Prime Minister's attention in ways that had not been seen before. The national broadsheet newspaper, The Australian, began talking about the 'green drought' and the media started reporting the Prime Minister's deep conviction to leave water reform as his legacy (Megalogenis, 2002a; Peatling, 2002; Wahlquist and Megalogenis, 2002). It seemed the Wentworth Group had finally managed to make environmental issues mainstream, succeeding where decades of environmental science and activism had failed before.

A second Blueprint on national water reform followed, and the group were commissioned by the New South Wales (NSW) State Premier to recommend reforms of native vegetation and natural resource management in that State (Wentworth Group, 2003a; 2003b). Their recommendations for regional governance have been largely implemented through NSW Catchment Management Authorities. They have been influential in achieving commitments from state and federal governments to increase environmental flows into the Murray Darling River system and to further the development of a national market in water trading. Individual members of the Group 
have continued to have high media profiles and have featured heavily in documentaries and news stories relating to environmental issues and water reform, as well as personal profile interviews and features. They also continued their high scientific and intellectual profiles through appearances as public lecturers at universities, and keynote and after dinner speakers at conferences relating to their role in the Wentworth Group and its rise to prominence in 2002. They have become firmly entrenched public experts on environmental issues in Australia, the first choice of politicians, journalists and conference organisers.

As a group of scientists outside the boundaries of formal institutions, the Wentworth Group differ significantly from other public experts. Unlike Jasanoff's science advisers who were shown to have undue influence over American government policy making, the Wentworth Group were not part of the formal institutions of government and policy formulation (Jasanoff, 1990). Although some of the members of the Group worked in government funded laboratories and held positions on official government advisory panels, the Wentworth Group formed independently of these organisations. The sponsorship of the Group by WWF Australia aided their status as 'nature's advocates' (Yearley, 1996), providing activist legitimacy and strategy to their lobbying of government and use of the media, although they remained independent of the NGO and were not accountable to its membership.

The Group's access to the Prime Minister and other senior politicians was facilitated by their individual roles in public institutions, but their advice was not constrained by the structures and processes of government and policy making. Breaching institutional boundaries, the position of the Group outside the structures of government, while individuals maintained strong relationships inside government proved to be the ideal point from which to maximise their influence on policy. This boundary riding also freed the Group from accountability to any particular constituency.

\section{Peter Cullen}

As spokesperson for the group, Peter Cullen has been particularly prominent as the most public face of the Wentworth Group, and subsequent to the events of 2002-3 he has been most prolific in giving speeches and media interviews explaining the Group's success. Prior to the formation of the Wentworth Group, his career highlights 
include being Dean of the Faculty of Applied Science at Canberra University and Executive Director for the Cooperative Research Centre in Freshwater Ecology. In 1997 he was elected President of the Federation of Australian Scientific and Technological Societies (FASTS), a role which held an ex-officio position on the newly established PMSEIC. In 2004 he was appointed an Officer of the Order of Australia and was awarded the Naumann-Thienemann Medal by the International Association of Theoretical and Applied Limnology (Commonwealth of Australia, 2004; International Association of Theoretical and Applied Liminology, 2005).

In 2003 one of the journalists present at the original dinner at the Wentworth Hotel, Asa Wahlquist, wrote a feature article on Cullen, who she describes as 'arguably Australia's leading environmental scientist', for the magazine section of the weekend edition of The Australian. Describing the political impact of his ability to translate the complex details of science into the language of politics she wrote:

Cullen's gift lies not just in understanding science, its broad sweep and its daunting, even damning, details. It is in his striving to find out where the listener stands, then talking his language and, as he puts it, going on a journey together. Cullen's fellow travelers include not only [NSW Premier Bob] Carr but also Prime Minister John Howard, who in 2001 named him Environmentalist of the Year. Cullen first grabbed Howard's attention in 1998, when he addressed the Prime Minister's Science, Engineering and Innovation Council on salinity. "When you are in a position like mine, you meet a lot of people," Howard explains, "and somebody who can explain a complicated issue in clear language and can provide a cut-through mechanism for beginning to tackle it always impresses you." (Wahlquist, 2003: 31-32)

\section{Successful Science Communication}

Cullen has been the most prominent member of the Wentworth Group in describing the factors that contributed to their success, including their science communication strategy. His explanations for the success of the Wentworth Group include the clarity and simplicity of their language and message, and their effective use of the media. In a public address to mark World Water Day in 2004, titled 'Turning the Tide: How Does Science Change Public Policy?' he pointed to four key issues.

The essence of the message is: 
- Clear and simple language that everyone could understand. No qualifiers, conditions or references

- Clear articulation of the problem, but strongly linked to realistic and effective solutions that could be implemented by governments if they wish

- No obvious self-interest in that we were not just calling for research funding

- The message kept focused on the key points and did not diverge to the many other interests the authors also feel passionately about (Cullen, 2004).

In the rest of his address, Cullen covered other factors he thought were significant in the success of the group. These include:

- Having three senior journalists on side, right from the initial dinner party;

- 'Staying on message', keeping focussed on the key points in the Blueprint;

- The media interest in the direct conflict with Alan Jones;

- What he calls the 'mystique' of the group, of senior scientists all meeting together on this very serious issue; and

- Being very effective in using the tools of modern mass media, including releasing the Blueprint on the internet.

The simplicity of the material and the lack of detail and equivocation in the message presented in the Wentworth Group blueprints provided an obvious target for criticism from within the scientific community. Writing in response to a critique by Lane et al. (2004) published in the journal Australian Geographical Studies Group member and geomorphologist Bruce Thom (2004) wrote:

... we make no excuses for the lack of evidence or comprehensive explanation of ideas expressed in the three Blueprints. Our aim was to put forward solutions to some NRM problems faced by our nation, in the simplest and clearest ways we felt appropriate, to help stimulate public debate. We think we achieved this aim (397).

The Wentworth Group's insistence on the need to keep their message simple and to keep qualifying statements, scientific disagreements and uncertainties out of public engagement is based on a strictly 'deficit model' of public understanding of science 
(Irwin and Michael, 2003). Peter Cullen is unequivocal in his insistence that while debate, uncertainty and contestability are essential and enjoyable elements of the scientific process, they must be kept out of the public eye. In a conference dinner address to the Australian Academy of Technological Sciences and Engineering he said:

Contestability is interesting in these public arenas, and this is where a strength of our science is also, in fact, our weakness. In science we are used to ideas being contested. In fact, we probably all enjoy the tussle of ideas and different interpretations of data and different models. That playing with alternative explanations is, I think, one of the great pleasures of science. But when the public hears those sorts of debates, they do not really understand the function of testing of hypotheses and testing of alternative solutions that goes on within science. When they see scientists disagreeing or arguing, they tend to believe either that one of the scientists is incompetent or that he has been bought off by some particular interest. Sometimes they just might understand that scientists might be marketing an idea to try and get research funds... But the public sees many claims from scientists, and this is where I think we face a sceptical audience. As someone quips, for every $\mathrm{PhD}$ there is an equal and opposite $\mathrm{PhD}$ (Cullen, 2003).

Cullen's whimsical reference to a phenomena of 'equal and opposite PhDs' hints at a relativist approach to the production of scientific knowledge, and his description of the joy of the contest shows astute awareness of the social processes of scientific knowledge production. However, far from this leading to an opening up of scientific debate to the public, Cullen strongly advocates the presentation of science to a suspicious public as simple, unequivocal facts which contribute to debate, but are not themselves open to debate. In the 2004 World Water Day speech Cullen again repeated the importance of communicating simple, unequivocal scientific facts to the public:

Simplification of complex issues is fundamental to communicating to a wider audience. Detailed references and qualifiers are inappropriate if ideas are to be got into the public domain. That is not to say that such subtleties are unimportant; just that they get played out in other arenas (Cullen, 2004). 
According to the Wentworth Model, scientific debate takes place in laboratories, at conferences and behind the closed doors of five star hotel dining rooms, but scientific facts must be presented to the public as clear, incontestable input into public and political debate. While scientists know the value of debate and the contestability of scientific knowledge, according to Cullen these social processes are beyond the comprehension of the public. Following the Wentworth Model, good scientific communication involves keeping the messy processes of knowledge making out of sight of the public, who are easily confused by science and uncertainty.

This contrasts with recent changes in the relationships between science and the public in other countries and in other Australian contexts. Deliberative forums, citizen juries, consensus panels and other initiatives in several different countries indicate that citizens are capable of dealing with the complexity of scientific uncertainty and indeed are demanding to be involved in decisions about the political implications of these uncertainties and risks (see for example Irwin, 1995; Guston, 1999; Joss, 1999; Irwin and Michael, 2003; Rowe et al., 2004). Citizen juries and deliberative polling have been used in environmental decision making in Australia, demonstrating that the move to a more open and accountable relationship between science and the public, which acknowledges the inherent uncertainty in scientific knowledge making, is not simply a northern phenomenon (Carson and Martin, 2002; Carson et al., 2002; Healy, 2005). In particular, changes in agricultural extension and natural resource management demonstrate that public involvement in the science of ecological management in Australia is more sophisticated than the strict deficit model presented by Cullen and the Wentworth Group (Black, 2000; Ross et al., 2002).

The Blueprint for a Living Continent acknowledges the need for local participation in decision making, but insists that this be based on 'world class science'. Lane et al. (2004) and Main (2004) have both pointed out the epistemological inconsistencies of this aim. Main highlights the cultural and political implications of a continued insistence on universal ecological scientific knowledge and disregard for more localised, intimate relationships between people and place in rural Australia, while Lane et al. are more critical of the recommended model of regional governance of natural resources. The neo-liberal Wentworth Group prescriptions for small government do not correspond to prescriptions for small science. Science remains 
'world class' beyond the understanding of the public, yet supports a devolution of political power to local and regional councils.

The Wentworth Group's insistence on keeping the social processes of science out of public view demonstrates an extended certainty of the power of science in leading towards rational resolution of complex social and political issues. This is far from the reflexive modernity of Beck's (1992) risk society in which scientists acknowledge the limits to certainty and their role in constructing novel risks. Managing natural resources in Australia is a fundamentally about managing risk. National policy defines drought as the risk that there will be insufficient rainfall to undertake agricultural and other human activities in any given year (Drought Policy Review Taskforce, 1990). It is a heterogeneous risk, a combination of human and natural causes. It is fundamentally a mismatch between the patterns of human settlement and agricultural activity, and the naturally variable climate of Australia. That the scientists who became most prominent in the public discourse of drought deliberately avoided speaking of uncertainty and contingency demonstrates that dealing with risk has not driven scientists in Australia to the kind of reflexivity expected in the risk society. However, neo-liberal policy has sought to place the management of drought risk into the hands of individual farmers or regional authorities and out of the control of the state (Higgins, 2001). It is within this wider neo-liberal discourse of natural resource management that the Wentworth Group strategically chose to present their solutions to the problems highlighted by the drought of 2002 .

\section{Policy Discourse}

While the Wentworth Group explain their success in terms of the simplicity and certainty of their message and their astute use of the media, further explanation of why they received such a positive reception by government can be found in the political pragmatism of their prescriptions. The Wentworth Group presented a fundamentally neo-liberal response to drought and natural resource management in Australia. Their Blueprint and subsequent publications and speeches emphasise market based water reform, paying farmers for services rather than providing basic welfare, and continuing the restructuring and 'adjustment' of agricultural industries to ensure that inefficient, ecologically destructive farmers either change their practices or leave the industry (Flannery, 2003; Wentworth Group, 2002; 2003a; 2003b). The 
Blueprint talks about the problems with farmers trying to deal with 'bureaucratic red tape', and they call for smaller, regionalised governance of natural resources, with an emphasis on business management models in administration. They call for greater involvement of the corporate sector in resolving Australia's environmental problems. They also call for major public investment, mostly for buying water to increase environmental flows in the Murray River, and provide some ideas for how this money might be raised. These include increasing food prices, an environmental levy, local and state government taxes and charges, government bonds and the full privatization of the partially publicly owned telecommunications corporation Telstra.

The ideological nature of the blueprints was highlighted in the critique by Lane et al. (2004) in Australian Geographical Studies. Centering on the recommendations for regionalised governance, this critique highlights the ideological, rather than scientific basis for these prescriptions. They point to the complexities of environmental governance and 'community empowerment' which are left out of the simple Wentworth recommendations, and call for a reassessment of public deliberation as the basis for deciding the future of Australian landscapes.

Although differing on whether it is a strength or a liability, critics and defenders basically agree that the Wentworth Group prescriptions fall firmly within dominant political agenda. Far from apologising for the presentation of science in the language of politics, in response to Lane et al. Peter Cullen is clear that this was a deliberate strategy.

As Lane et al. (2004) say "the ideas of the group apparently enjoy considerable policy influence with the current federal administration. Indeed there are a number of obvious parallels between the Group's approach and the trajectory of the current Federal Government's thinking on key areas of environmental policy, including decentralization." It may be flattering to assume causality here but the Federal Government's thinking on these areas was laid down before the Blueprint was released, so it is more likely that we chose to operate within the model already established by Government. (Cullen, 2004, emphasis in original) 
Peter Cullen and the Wentworth Group became recognised as public experts because of their simple communication style and their political pragmatism. Their rise to prominence is explicable in terms of their ability to translate serious environmental problems into policy solutions which are compatible with, rather than challenge the political status quo. They are not politically aligned, but they are politically pragmatic. As 'concerned scientists', they claim political independence and freedom from the constraints of bureaucracy. Their success in communicating science to the public and to politicians comes with the freedom to speak without the qualifiers of either science or policy formulation. Under this formulation, closeness to the Prime Minister for a scientist is a sign of the ability to clearly communicate truth to power, rather than a sign of political allegiance or cooption. For Cullen, formulating scientific ideas in the language of governing politicians is simply part of the 'journey'.

\section{Sparking Debate}

Whilst being very deliberate in not opening the process of scientific debate to the public, and not challenging the political status quo, the Wentworth Group consistently state that their aim was simply to bring their ideas into the public arena where they could be debated. For Cullen, participation in this debate is a moral obligation:

Australia needs to have a vigorous public discourse about how we manage our land and water, and scientists and academics funded from the public purse have an obligation to contribute to this discourse (Cullen, 2004)

Under the Wentworth Model, the terms of this debate are clear. Media friendly scientists must communicate in simple language, keeping scientific contests out of the public eye, while simultaneously being solutions focussed and politically pragmatic. Scientific contributions to public debate about the future of Australia's landscapes should provide solutions rather than endlessly pointing out problems, but they should not challenge the dominant neo-liberal political discourse, nor should they reveal the uncertainties and equivocation inherent in scientific knowledge production.

Speeches and interviews with Cullen and other Wentworth Group members repeatedly stress that their success was due in large part to providing solutions, rather than asking for more research funds to define the problem. In her profile of Cullen, 
Wahlquist wrote that Cullen is '...proud of the fact that the group provides solutions', quoting him further:

"The community is sick of scientists listing the problems. They want solutions and we think we have got ways forward on these issues. That is the real value we are adding." (Wahlquist, 2003: 31)

In his response to the Lane et al. critique, the importance of being solutions-focussed took on a new urgency, further defining the model by which scientists should engage with public issues in Australia.

We did not pretend that the Blueprint was the only solution to these difficult problems, or even that it was the best solution. We said it was an effective solution, and invited anyone with a better solution to bring it forward. If critics like Lane et al. (2004) have a better solution they should bring it out rather than making self-serving calls for more research funding for studies of regional governance (Cullen, 2004).

As a highly recognised and awarded exponent of scientific communication and engagement with the public and politicians in Australia, Cullen is clear that the time for critique, problem definition and deliberation is over. In his view, publicly funded scientists and academics are not only obliged to contribute to public debate, they must contribute solutions rather than pointing out further problems or gaps in knowledge.

The response to a second critique, an editorial by Daniel Lunney (2003a) in the relatively obscure Australian Zoologist, further clarifies the terms of the debate which the Wentworth Group defined. Lunney made similar criticisms about the lack of detail in the Blueprint and highlighted the importance of continued funding of scientific research, but was highly supportive of the political nature of the document.

The Blueprint presents an economic model couched in words of great clarity, but the subtext is numerical and this allows one to convert words to numbers, numbers to dollars, and dollars to policy, such as in relation to property rights (both water and land), compensation, improving market signals, tax systems support, eliminating hidden subsidies and improved regulation, that controls the flow of dollars and has the potential to produce a better agricultural system for Australia (345). 
Group member Bruce Thom contrasted Lunney's 'constructive criticism', which was supportive of the basic political and economic agenda of the Blueprint, with Lane et $a l$.'s lack of concern for the 'substantive prescriptions for environmental reform':

The contrast between the Lane et al. commentary and that of Lunney (2003)... is quite stark. Lunney's critique... is much more comprehensive, recognising that:

The Blueprint is compulsory reading for all those who share the struggle to conserve Australia's biota and its life support systems, the soil, air and water... the Wentworth Group deserves serious consideration when it is backed by a major NGO [non-governmental organisation] and governments start quoting it. Given its importance, and the likelihood that governments and conservation groups will use it as a platform for change, the document deserves a serious critique (Lunney, 2003, p. 345, my [Thom's] italics) (Thom, 2004: 393).

Thom makes much of Lunney's contribution to the 'iterative process of putting forward ideas, listening to criticism and then producing a new generation of ideas', as the model of debate that Wentworth Group aimed to be part of. By implication, more fundamental, political critique such as that of Lane et al. is not in the spirit of moving ideas forward. While deserving of a response in the journal where their commentary was published, Lane et al. are clearly considered to be outside the constructive debate that continues amongst scientists and politicians within the boundaries of existing political discourse.

Under the Wentworth Model the terms of debate are couched in pragmatism. This means that the possibilities for dissent, for critical approaches to the complex problems of agriculture and land management in Australia are constrained. With a few very prominent senior scientists setting the environmental and scientific agenda firmly in line with the dominant political agenda and responding to criticism by stating the need for pragmatic solutions rather than over complicating the problems, the possibility for fundamental, long-term change in how Australians relate to land and water becomes limited. The constraints on more fundamental scientific contributions to public debate about the ecological future of Australia became apparent in the reception of a second report, Future Dilemmas, co-incidentally released in late 2002 . 


\section{Future Dilemmas}

The rise of the Wentworth Group coincided with the release of a major scientific report on the environment and population in Australia, which similarly aimed to provide a new contribution to public debate on the future of Australian landscapes and society. The Future Dilemmas report by scientists in Commonwealth Scientific and Industrial Research Organisation's (CSIRO) Sustainable Ecosystems group was released in November 2002, addressing the topic of population growth scenarios and their impacts on natural the resources and the ecology of Australian landscapes (Foran and Poldy, 2002). While the Wentworth Group talked broadly about living in the landscape, the Future Dilemmas report sought to provide detailed answers to questions about how many people can live in the landscape and under what conditions. Unlike the Wentworth Group's Blueprint, Future Dilemmas was widely denounced by the media and government, and comparing the different outcomes points to some of the broader implications of the Wentworth model of pragmatic science communication for public debate in Australia.

Commissioned by the Department of Immigration and Multicultural and Indigenous Affairs, the report by Barney Foran and Franzi Poldy was controversial even before its release. The results presented in the report were the output of modeling of Australia's 'physical economy', the material physical and biological processes that underpin the 'monetary economy' (Pyper, 2003). Citing the exclusion of the relationships between the monetary and physical economies, such as the impact of pricing on resource use, as a fundamental flaw in the CSIRO modeling, University of Melbourne economist Mark Wooden dissented from the report's steering committee and spoke out against its findings in the media.

The response to Future Dilemmas was particularly vitriolic in Murdoch Press's The Australian, with the basic editorial line seeming to be that the report was driven by a deep green environmental agenda, which called into question the scientific objectivity of the CSIRO. For example:

Beneath this long-awaited CSIRO report is a fusion of scientific process and green-based religion... scientific dogmatism has undermined this project and the CSIRO's reputation (Kelly, 2002: 28) 
and

... the CSIRO study, despite the author's claim to be dispassionate, is anything but neutral. It is driven by a deep green environmental philosophy that finds the Western growth model repugnant and unsustainable... it is too deeply flawed by green hysteria to be the basis for sensible policy. It raises some basic questions about the impartiality of the CSIRO on environmental matters. (Wood, 2002: 11)

Within the generally vitriolic editorial line, an article in The Australian by George Megalogenis (2002b) provides a telling insight into why the Wentworth Group received such a comparatively good reception.

The seeming contradiction, where one branch of the CSIRO is lauded [Wentworth] and another branded as Luddite [Future Dilemmas], has been prompted by the people who think they have the most to lose from this new discussion - the economists who have dominated public policy over the past two decades.

University of Melbourne economist Mark Wooden said the two reports were "not in the same league".

"I think that good science will be surprisingly compatible with economics, and you only have to see that with the Wentworth Group", the professional (sic) fellow with the Melbourne Institute for Applied Economic and Social Research said this week. (emphasis added)

As well as being criticised for being incompatible with economics, Future Dilemmas was criticised from within the scientific community as being too equivocal and inaccessible to the general reader. Poor communication skills and the lack of credible policy solutions to the problems they highlighted were blamed for the failure of the Future Dilemmas report by Daniel Lunney (2003b). His largely positive critique of the Wentworth Group used Future Dilemmas as a contrasting example of poor scientific communication:

The strengths of the Blueprint are that it is brief, well-written and positive. It achieves what the Future Dilemmas report did not: it has become a guide to 
government action. The difference lies partly in the clarity of the writing, which was an impediment in the Future Dilemmas report (Lunney, 2003a: $345)$.

According to Lunney, the Wentworth Group were able to speak truth to power because they spoke the clear, simple language of power. By contrast, the Future Dilemmas authors were presented as bad scientists because of their inability to break through to policy makers and the mainstream media. Despite attempts to stay objective in their numerical analysis, they were presented at best as politically naïve and poor writers and at worst as green ideologues disguised as government scientists. Economists, newspaper editors and government ministers were justified in ignoring or vilifying the Future Dilemmas report because it did not fit within the dominant neoliberal political agenda. Other scientists explained its poor reception on the reticence of the authors to provide clear policy prescriptions and on their use of complex technical language. These two strains of criticism both used explicit reference to the pragmatic, simplistic approach of the Wentworth Group by way of comparison.

In assessing the response to Future Dilemmas it becomes apparent that in 2002 the Wentworth Group not only emerged as a coherent source of environmental expertise, but they also set the style and political tone for engagement between science, the media and politics in Australia. Scientists who do not conform to the Wentworth Model of scientific contribution to public debate should expect to be harshly judged, if not ignored, not only by the media and politicians, but also by their peers.

\section{Conclusion}

Comparing the fate of the Future Dilemmas report with the Wentworth Group and their blueprints indicates that in order to be taken seriously in public debate in Australia science should: present clear, unequivocal facts in simple language to an easily confused public; work within, rather than challenge the dominant political agenda; and present solutions rather than describe problems. Furthermore, following the Wentworth Model, policy influence is achieved by working across the boundaries of government and non-government organisations, using personal networks and positions of influence, rather than working within existing structures of government and bureaucracy. 
The Wentworth Group present a model of scientific expertise operating at a distance from a simple minded public, positioned firmly within the dominant political framework, yet without accountability to any particular constituency. This seems reactionary given the many of the shifts in the relationship between science, the public and politics in Western democracies over the last 30 years, and presents several challenges to earlier depictions of this relationship in liberal democratic societies. Drought is heterogeneous risk, of both natural and human origins, but it has not called forth Beck's (1992) risk society and its reflexive scientists in Australia. The Wentworth Group have become expert advisors to government, although they remain largely outside the structures of government in which Jasanoff's (1990) American experts operate. Their 'scientific' advice was clearly shaped to fit the dominant neoliberal political agenda, but far from denying it or being concerned about how this might influence their scientific objectivity, the Wentworth Group claim this to be one of the key elements of their strategy for communicating science to government. Environmental science in Australia remains highly contestable, both scientifically and politically, yet the Wentworth Group's insistence on keeping contingency and uncertainty behind the closed doors of scientific meetings and out of the public eye is in sharp contrast to recent movements towards increasing public access to the scientific decision making (Irwin, 1995; Irwin and Michael, 2003; Joss, 1999).

This case study of antipodean scientists responding to public discussions about drought demonstrates the contingent nature of the relationships between science and politics in liberal democracies. Whilst the pragmatism of the Wentworth Group is no doubt strongly shaped by their national context, the strength of their belief in the deficit of public understanding, their deliberate positioning within the dominant political discourse, and their expert position beyond accountability to any definable constituency, represents a new alignment of political strategy with scientific expertise. Their model of the relationship between science and public policy was largely successful in achieving their immediate aims of achieving reform of natural resource management, at the expense of more critical engagement between the scientists, communities and governments coming to terms with complex ecological problems.

\section{References}


Ball, J, L Donnelley, P Erlanger, R Evans, A Kollmorgen, B Neal and M Shirley 2001. Inland Waters: Australia State of the Environment Report 2001 (Theme Report), Canberra: CSIRO Publishing on behalf of the Department of the Environment and Heritage.

Beck, U 1992. Risk Society. London: Sage.

Bell, S and M Moller (2006). The green drought. Australian Humanities Review. Available at <http://www.lib.latrobe.edu.au/AHR/archive/Issue-April2006/EcoBell.html>, last accessed 18 September 2006.

Black, A 2000. Extension theory and practice: a review. Australian Journal of Experimental Agriculture, 40, 493-502.

Bonyhady, T 2000. The Colonial Earth. Melbourne: University of Melbourne Press.

Botterill, L C and M Fisher 2003. Beyond Drought: People, Policy and Perspectives. Melbourne: CSIRO Publishing.

Carson, L and B Martin 2002. Random selection of citizens for technological decision making. Science and Public Policy, 29(2), 105-113.

Carson, L, S White, C Hendriks and J Palmer 2002. Community Consultation in Environmental Policy Making. The Drawing Board, 3(1), 1-13.

Commonwealth of Australia 2004. Australian Honours List. It's an Honour. Available at <http://www.itsanhonour.gov.au/honours_list/resultDetail.cfm?awardsID=1056762>, last accessed 23 December 2005.

Cullen, P 2003. Address to the Conference Dinner, ATSE Focus. 128, Available at <http://www.atse.org.au/index.php?sectionid=494>, last accessed 23 December 2005. 
Cullen, P 2004. Turning the Tide: How Does Science Change Public Policy. World Water Day Address, Adelaide: CSIRO Land and Water Seminar, 22 March. Available at <http://www.thinkers.sa.gov.au/images/Cullen_World_Water_Day.pdf>, last accessed 3 January 2006.

Downey, G L 1988. Reproducing Cultural Identity in Negotiating Nuclear Power: The Union of Concerned Scientists adn Emergency Core Cooling. Social Studies of Science, 18, 231-264.

Drought Policy Review Task Force, 1990. National Drought Policy. Volume 1. Canberra: Commonwealth of Australia.

Flannery, T 2003. Water: Oil of the $21^{\text {st }}$ Century, School of Graduate Studies Dean's Lecture, Melbourne: University of Melbourne, 13 October. Available at <http://www.gradstudies.unimelb.edu.au/prog_services/deanlectures/pdf/water.pdf>, last accessed 3 January 2006.

Foran, B and F Poldy, 2002. Future Dilemmas. Options to 2050 for Australia's population, technology, resources and environment. CSIRO Resource Futures Working Paper 02/01, Canberra: CSIRO Sustainable Ecosystems.

Grimm, N 2002. Scientists condemn drought-proofing of continent. AM. ABC Online. Avilable at <http://www.abc.net.au/am/s698876.htm>, last accessed 7 April 2004.

Guston, D 1999. Evaluating the First U.S. Consensus Conference: The Impact of the Citizens' Panel on Telecommunications and the Future of Democracy. Science, Technology and Human Values, 24(4), 451-482.

Healy, S 2005. Toward a Vocabulary for Speaking of the Engagement of Things into Discourse. Journal of Environmental Policy \& Planning, 7(3), 239-256.

Higgins, V 2001. Calculating climate: 'advanced liberalism' and the governing of risk in Australian drought policy Journal of Sociology, 37(3), 299-316. 
International Association of Theoretical and Applied Limnology 2005. Naumann$\begin{array}{lllll}\text { Thienemann } & \text { Medal. } & \text { SIL. } & \text { Available }\end{array}$ <http://www.limnology.org/people/naumann_thienemann.html>, last accessed 23 December 2005.

Irwin, A 1995. Citizen Science. London and New York: Routledge.

Irwin, A and M Michael 2003. Science, Social Theory and Public Knowledge. Maidenhead and Philadelphia: Open University Press.

Jasanoff, S 1990. The Fifth Branch. Cambridge, Massachusetts and London, England: Harvard University Press.

Joss, S 1999. Public participation in science and technology policy- and decsionmaking - ephemeral phenomenon or lasting change? Science and Public Policy, 26(5), 290-293.

Kelly, P 2002. Deep green dilemma. The Australian, 9 November, 28.

Lane, M, G T McDonald and T Morrison 2004. Decentralisation and Environmental Management in Australia: a Comment on the Prescriptions of the Wentworth Group. Australian Geographical Studies, 42(1), 103-115.

Lunney, D 2003a. A way forward, yes; a Blueprint for a living continent, no: a critical look at the Wentworth group's report of November 2002. Australian Zoologist, 32(3) 345-350.

Lunney, D 2003b. Thoughts on good writing and the recent CSIRO Report. Future Dilemmas. Australian Zoologist, 32(2), 203-206.

Main, G 2004. Red Steers and White Death: fearing nature in rural Australia. Australian Humanities Review, 33. 
Megalogensis, G 2002a. Howard turns his mind to establishing a legacy. The Australian, 2 November, 2.

Megalogenis, G 2002b. Pragmatic PM sees green future. The Australian, 8 November, 4.

Peatling, S 2002. Radical plan to wean Australia off its European-style water wastage. The Sydney Morning Herald, 4 November, 1.

Pyper, W 2003. Future Dilemmas. Ecos, 117, 26 - 28.

Ross, H, M Buchy and W Proctor 2002. Laying Down the Ladder: A Typology of Public Participation in Australian Natural Resource Management. Australian Journal of Environmental Management, 9, 205-217

Rowe, G, R Marsh and L. Frewser 2004. Evaluation of a Deliberative Conference. Science, Technology and Human Values, 29(1), 88-121.

Thom, B 2004. Response to Lane et al.. (2004): Decentralisation and Environmental Management in Australia: A Comment on the Prescriptions of the Wentworth Group. Australian Geographical Studies, 42(3), 393-397.

Wahlquist, A 2003. Man with a plan. The Weekend Australian Magazine, 31 May, 3133.

Wahlquist, A and G Megalogenis 2002. Our greenest drought. The Australian, 26 October, 22.

Walker, K 1994. The Political Economy of Environmental Policy: An Australian Introduction Sydney: UNSW Press.

Ward, R 1966. The Australian Legend. Melbourne and London: Oxford University Press. 
Wentworth Group 2002. Blueprint for a Living Continent. Sydney: WWF Australia.

Wentworth Group 2003a. A New Model for Landscape Conservation in New South Wales. Sydney: WWF Australia.

Wentworth Group 2003b. Blueprint for a National Water Plan. Sydney: WWF Australia.

Wood, A 2002. Narrow views on broadening population. The Australian, 5 November, 11.

Yearley, S 1996. Nature's advocates: putting science to work in environmental organisations. In Misunderstanding Science? A. Irwin and B. Wynne, pp 172-190. Cambridge: Cambridge University Press. 